Article

\title{
Sustainability and Competitiveness in Australian Cities
}

\section{Richard Hu}

Globalization and Cities Research Program, University of Canberra, Bruce ACT 2601, Australia; E-Mail: richard.hu@canberra.edu.au; Tel.: +61-2-6201-2051

Academic Editor: Steffen Lehmann

Received: 15 November 2014 / Accepted: 4 February 2015 / Published: 10 February 2015

\begin{abstract}
This study injects sustainability into competitiveness to inform policy making and planning for contemporary urban development. This is built upon the recent advancement in the scholarship on urban competitiveness that demonstrates a clear deviation from an economic-centric approach to incorporate multiple dimensions of a city's progress. This study has an explicit concern for environmental sustainability and its relationship with urban competitiveness and their conceptual and methodological articulations. Empirically, this study measures the sustainability and competitiveness in Australian cities and reveals that Australia's urban progress is clearly associated with an environmental cost. The findings are useful to inform policy making and planning for building sustainable and competitive cities. Apart from the conventional solutions that focus on urban form change and transport infrastructure improvement, this study suggests a need to explore the opportunities deriving from the emerging smart city planning and practice.
\end{abstract}

Keywords: sustainability; competitiveness; urban development; Australian cities

\section{Introduction}

Sustainability and competitiveness are two major challenges facing contemporary cities. However, their relationship has not been well understood, which has impacted effective policy making and planning for building sustainable and competitive cities. This study fuses sustainability and competitiveness, conceptually and methodologically, to inform urban development. It injects sustainability into the urban competitiveness discourse, which has been evolving from being economic-centric to being increasingly incorporative of multiple dimensions of a city's performance, including environmental sustainability [1,2]. There have been debates on whether and how cities compete [3-6]. The underpinning argument for 
urban competitiveness is that cities do not complete as firms do, but compete in more complex ways for more complex goals; some cities provide better environments than others for firms to do business, and a city's competitiveness is related to its mix of attributes for business operations $[7,8]$. More recent literature challenged the economic-centric approach to urban competitiveness and argued for a balanced approach that reflects a city's economic, environmental and social development [2,9]. However, scholars differ in the conceptualization and methodology, as indicated in the next literature review section.

This study has an explicit concern for a city's sustainability and competitiveness, to unpack their relationship, and it applies them to Australian cities. Conceptually and methodologically, this study clarifies the relationship between sustainability and competitiveness out of scholarly contestations. Empirically, it provides the most comprehensive understanding of the sustainability and competitiveness in Australian cities to inform policy making and planning. This article is structured as follows. The next section is a literature review of studies that include environmental sustainability in the conceptualization and measurement of urban competitiveness. The third section is on the method of data collection and analysis. The fourth section presents the results of competiveness, sustainability and their relationship in Australian cities. The article concludes with a discussion of the results and implications for policy making and planning for sustainable and competitive cities.

\section{Environmental Sustainability and Urban Competitiveness}

Despite its conceptual and methodological contestations, the scholarship on urban competitiveness has indicated a clear trend of moving from being economic-centric to incorporating the economic, social and environmental dimensions of a city's progress (see [1,2]). This review scopes the studies that have included environmental sustainability into urban competitiveness to inform the theoretical framework and design of this study. Economic performance (competitiveness) and environmental performance (sustainability) are effectively interrelated, may they be sector-based [10] or spatially-based [11]. Yet, the practical and conceptual co-existence (or fusion) of these two agendas is not always easy [11]. This review concerns the fusion of sustainability and competitiveness, which is spatially based and has been empirically applied to cities. Among the rich literature on urban competitiveness, studies that include environmental sustainability are recent and few. They can be classified into two broad strands. One strand remains economic-centric in approaching urban competitiveness, but incorporates environmental sustainability as a minor component. The other strand clearly articulates a balanced approach to urban competitiveness that highlights environmental sustainability as a major component. They are summarized in Table A1.

For the first strand of literature, the economic-centric approach to a city's competitiveness starts to consider environmental sustainability. Where urban competitiveness is defined as a city's ability to attract capital, businesses, talent and visitors as a holistic concept, the environment and natural hazards are considered a determining factor [12]. Where urban competitiveness is defined as a city's efficiency at producing wealth and providing welfare, measured by GDP, ecological environment is considered as a driving factor [13]. Where urban competitiveness is based on regeneration- and property-linked business strategies, the sub-indicators include the ecological footprint and environmentally responsible property development [14]. Empirically, these studies measured the competitiveness of cities across the world, Chinese cities and Indian cities, respectively. Although economic performance dominated these 
studies on urban competitiveness, they responded to the contemporary sustainable imperatives of the ecological footprint and climate change and included them in the measurement of a city's competitiveness. It is worth noting that The Economist Intelligence Unit [12] included environmental governance as a city's competitive factor. This is new among the studies that mostly focused on the technical indicators of a city's environmental performance.

The second strand of literature employs a balanced approach to urban competitiveness that includes environmental sustainability as a major component. Although these studies have various dimensions of urban competitiveness, the common core dimensions include economic competitiveness, social competitiveness and environmental competitiveness $[1,2,9,15,16]$. This balanced approach suggests an equal importance of these dimensions, marking a significant scholarly advancement from the economic-centric approach to urban competitiveness. Other dimensions of urban competitiveness include governance [2], culture [2,15], location [15] and external connection or connectivity [2,16]. These studies suggest a suite of indicators to measure a city's environmental performance. The commonly-used indicators include air, water, waste, vehicle and green space. Among the technical measures of environmental performance, pollution treatment and control are considered in two studies for competitiveness in Chinese cities [15,16]. Combined with the first strand of literature that includes environmental governance, these studies suggest an increasing awareness of the importance of environmental solutions in urban competitiveness.

Methodologically, both strands of literature employ two approaches to environmental sustainability and urban competitiveness. The majority of them built a composite urban competitiveness index that includes environmental sustainability either as a minor component $[12,14]$ or as a major component $[2,9,15,16]$. Two studies employed an explanatory approach, in which environmental performances were treated as explanatory factors of a city's competitiveness that was defined and measured otherwise. Ni et al. [13] had a heavily economic-centric conceptualization of urban competitiveness and measured it by a city's GDP performances only. Although their framework did include the ecological environment as a driving factor of urban competitiveness, it was not included as an explanatory variable in the empirical analysis of the competitiveness of 25 Chinese cities. Hu [1] expanded the conceptualization of urban competitiveness to define and measure it as a city's progress in growing jobs, attracting people and offering high value-added opportunities. The explanatory approach included environmental sustainability (together with economic and social performances) as a determining factor of a city's competitiveness and empirically measured their relationship.

Two advances in the literature have underpinned this study. One is the increasing recognition of environmental sustainability as an important dimension of urban competitiveness. The other is the explanatory approach to unpack the relationship between urban competitiveness and its multiple dimensions, including environmental sustainability. This study focuses on the specificity of the relationship between environmental sustainability and urban competitiveness and empirically applies it to Australian cities. 


\section{Methods}

This study measures sustainability and competitiveness in Australian cities. It includes 18 major Australian cities with a population of more than 100,000 (see Figure 1), which were identified in the national urban policy [17]. The national urban policy also envisioned a productive, sustainable and liveable future for Australian cities [17]. Four State of Australian Cities annual reports have been produced to report the progress of Australian cities in terms of productivity, sustainability and liveability [18]. The Australian Government's urban policy vision and reports have also informed the design of this study and where it should advance. They suggested the policy imperative for sustainable Australian cities and measured Australian capital cities against a suite of indicators. However, the State of Australian Cities report series did not provide a consistent set of indicators to measure the sustainability of all 18 major Australian cities. This has impacted their effectiveness in informing urban policy making and planning. Built upon the above literature review and the sustainable vision in the Australian national urban policy, this study injects sustainability into competitiveness and measures them for all 18 major Australian cities.

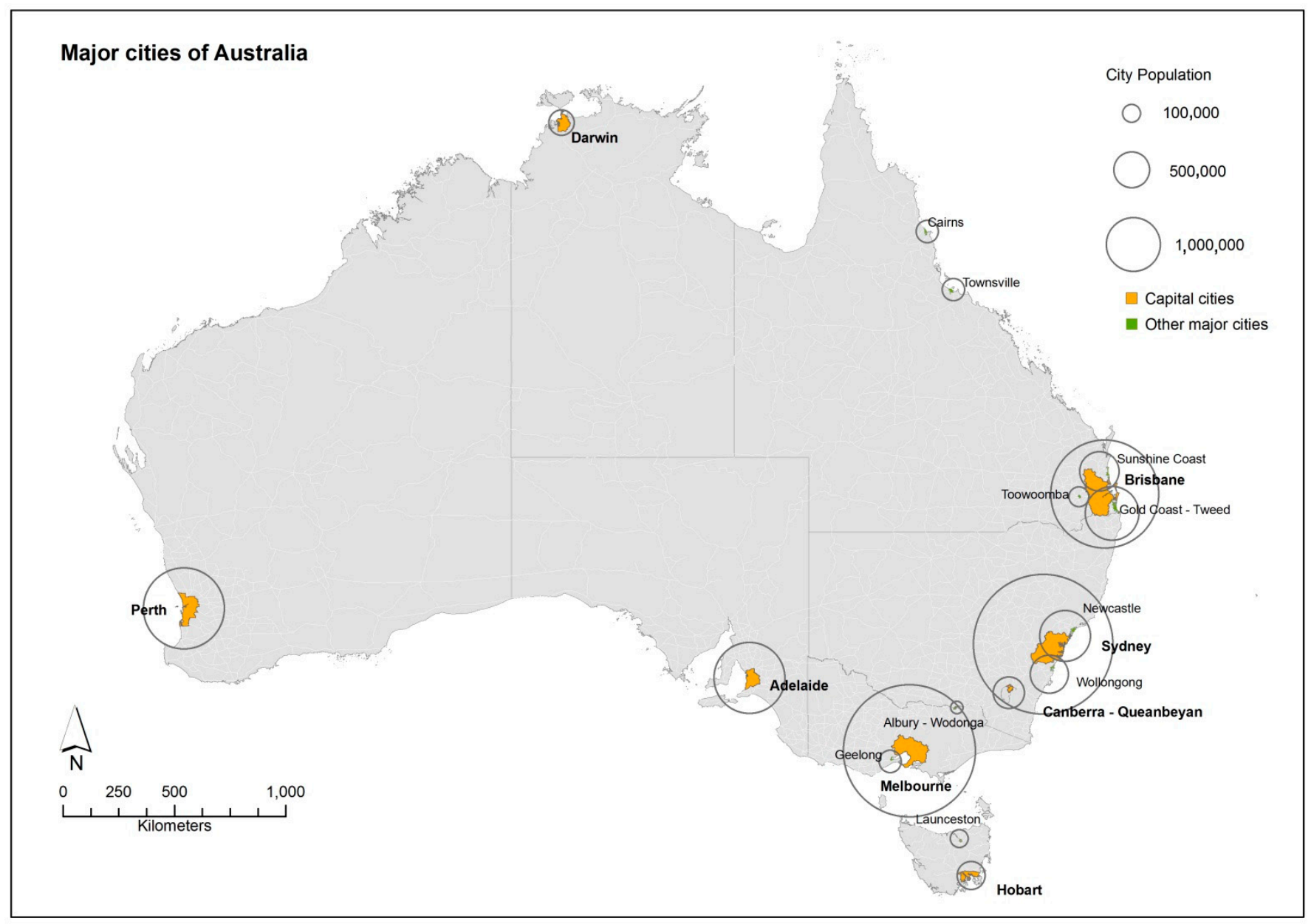

Figure 1. Eighteen major Australian cities. Source: produced with a reference to State of Australian Cities 2013 [18] (p. 20). 
This study uses the definition of a city's competitiveness as its progress in growing jobs, attracting people and offering high value-added opportunities [1]. This definition captures a city's economic performance, in particular the knowledge-based economic sectors. It also captures a city's attraction of people, which is a function of both economic and non-economic attributes. It is measured by three variables - employment, population and income - to build a composite urban competitiveness index as follows:

Urban competitiveness index $=\% \Delta$ population $+\% \Delta$ employment $+\% \Delta$ income

The data are collected from the Australian Census 2006 and 2011 to measure the variables' inter-censual changes in 2006-2011. Data for employment and income are based on place of work, and data for population are based on place of usual residence. The rationale is that the place of work data better reflect a city's economic performance and the place of usual residence data better reflect a city's economic and non-economic attributes that contribute to a city's attraction of people.

This study employs an explanatory approach to the relationship between a city's sustainability and competitiveness. The selection of the indicators of sustainability is informed by the literature review above and the indicators used in the State of Australian Cities reports [18]. Their measures and data sources are indicated in Table 1 . The values of the sustainability indicators and the urban competitiveness index will be standardised using the z-score to find out to what extent a city's sustainability can explain its competitiveness. Given the high correlation between the sustainability indicators (see Section 4.3 for details), a factor analysis will be useful to extract the common component to further explore the relationship between sustainability and competitiveness in cities. However, the sample size of 18 Australian cities is too small to enable a valid factor analysis. As a result, the relationship between sustainability and competitiveness will be examined through the four sustainability indicators, respectively. Further, a typology of Australian cities will be developed according to their sustainability and competitiveness performances.

Table 1. Sustainability indicators, measures and data sources.

\begin{tabular}{lll}
\hline \multicolumn{1}{c}{ Indicators } & \multicolumn{1}{c}{ Measures } & \multicolumn{1}{c}{ Data Sources } \\
\hline \multirow{2}{*}{ Ecological footprint } & $\begin{array}{l}\text { Land resources per person } \\
\text { per year (hectares) }\end{array}$ & $\begin{array}{l}\text { Australian Conservation } \\
\text { Foundation, 2007 }\end{array}$ \\
\hline \multirow{2}{*}{ Greenhouse pollution } & $\begin{array}{l}\text { Greenhouse pollution per } \\
\text { person per year (tonnes) }\end{array}$ & $\begin{array}{l}\text { Australian Conservation } \\
\text { Foundation, 2007 }\end{array}$ \\
\hline \multirow{2}{*}{ Transport use } & $\begin{array}{l}\text { Proportion of people using public } \\
\text { transport, walking, car sharing } \\
\text { or riding to commute (percentage) }\end{array}$ & Australian Census, 2011 \\
\hline \multirow{2}{*}{ Water use } & Water usage per person & $\begin{array}{l}\text { Australian Conservation } \\
\text { per year (litres) }\end{array}$ \\
\hline
\end{tabular}

\section{Results}

\subsection{Urban Competitiveness Index}

The 18 major Australian cities vary significantly by population sizes, ranging from more than four million to less than 0.2 million. They are classified into four groups according to their population sizes; within 
each group, they are sequenced according to their urban competitiveness index values (see Figure 2). Of the 18 cities, Perth and Brisbane had the highest urban competitiveness index values. Further, Perth demonstrated the highest growth rate in all of the three indicators of population, employment and income in 2006-2011. Between the two largest Australian cities, Sydney and Melbourne, Melbourne had stronger growth in the three indicators of population, employment and income and, thus, the overall urban competitiveness index. In the national context, they are facing increasing competition from smaller cities that are growing faster, Perth and Brisbane in particular. The national capital city region, Canberra-Queanbeyan, had the fourth highest urban competitiveness index value and the highest urban competitiveness index value in the third group of cities with a population of $0.2-1$ million. All of the Australian cities demonstrated growth in the three indicators to various degrees, except for Albury-Wodonga, which had a slight employment decline by one percent in 2006-2011.

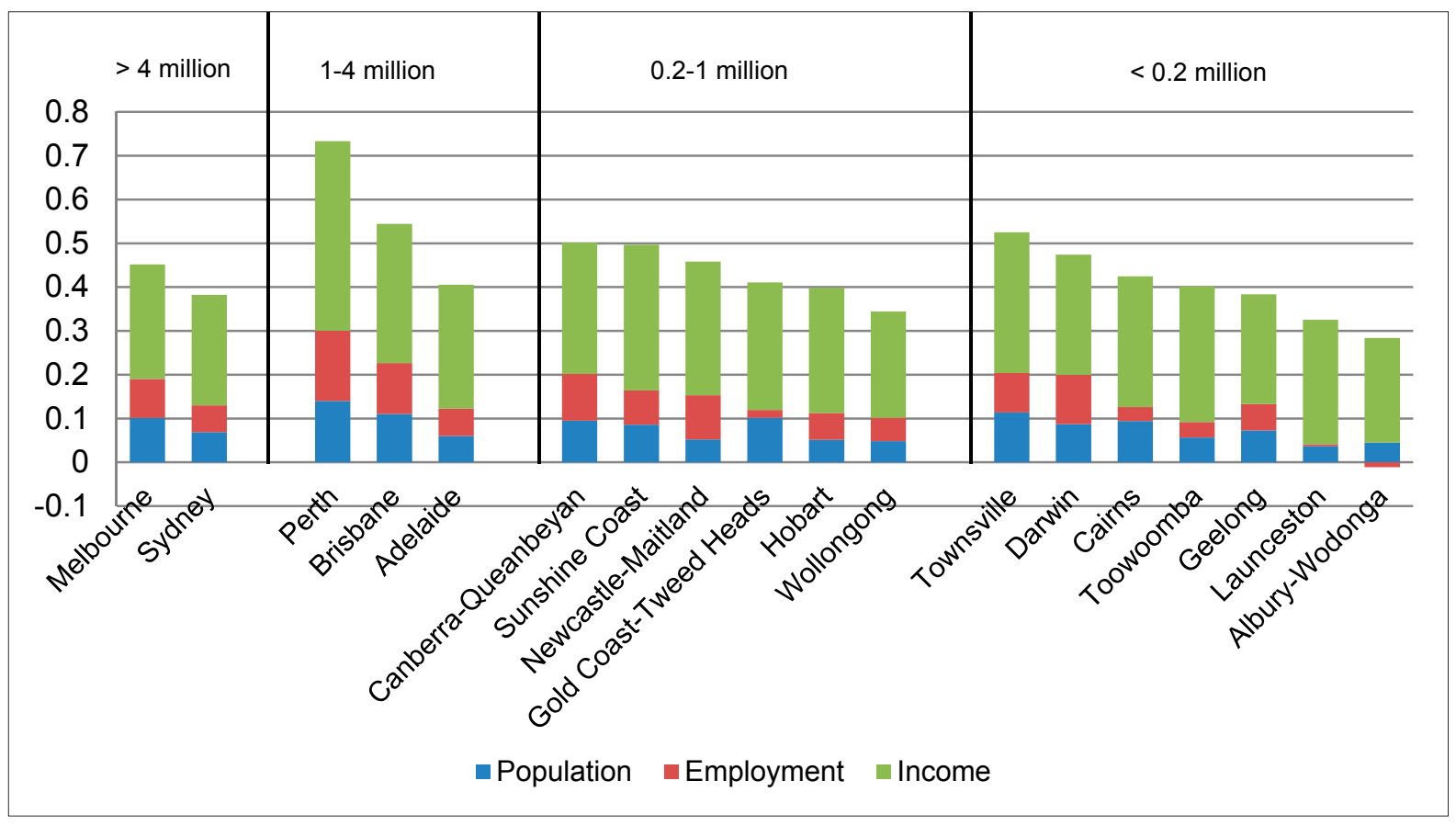

Figure 2. Urban competitiveness index of major Australian cities.

\subsection{Sustainability Indicators}

Australian cites are ranked according to their performances in the four sustainability indicators, respectively (see Figure 3). Ecological footprint is measured by the amount of land required to supply the resources demanded to sustain local residents. Australia had the fourth largest ecological footprint in the world, at 6.4 hectares per person per year [19]. Of the major Australian cities, Hobart had the smallest ecological footprint, requiring only 5.6 hectares per person per year. This is followed by other regional centres, including Launceston, Albury-Wodonga and Geelong. All of the eight major cities with ecological footprints below the national average are regional centres. Perth had the largest ecological footprint, at 7.6 hectares per person per year. It is followed by Townsville, which is the only regional city to have one of the nine largest ecological footprints. Melbourne was the closest state capital to the national average, requiring 6.5 hectares per person per year. 
The ecological footprint is the most representative of a city's overall environmental performance, while the other three indicators reflect a city's specific environmental performance. In terms of greenhouse pollution, Hobart and Launceston had notably lower amounts of greenhouse pollution than other major Australian cities. The two Tasmanian cities produced around 15 tonnes of greenhouse pollution per person per year. At the other end of the spectrum, Townsville and Sydney produced the most greenhouse pollution, at around 24 tonnes per person per year. Metropolitan regions tend to have higher rates of commuting by non-driving, largely due to the better provision of public transit infrastructure. Sydney had the highest proportion of people using sustainable transport, with 36 percent of workers opting to use an alternative to a car, followed by Brisbane and Melbourne. Smaller regional centres had the lowest proportions of sustainable transport use, particularly Albury-Wodonga, Newcastle-Maitland and Toowoomba. Australia is particularly prone to droughts and water shortages. Residents in Sydney used more water on average than any of the other Australian cities, at 816,000 L per person per year. This puts Sydney's water usage at almost 100,000 L more than the national average (722,000 L). Townsville and Canberra-Queanbeyan are the next highest per capita water consumers. Albury-Wodonga had the least amount of water usage, at 630,000 L per person per year.

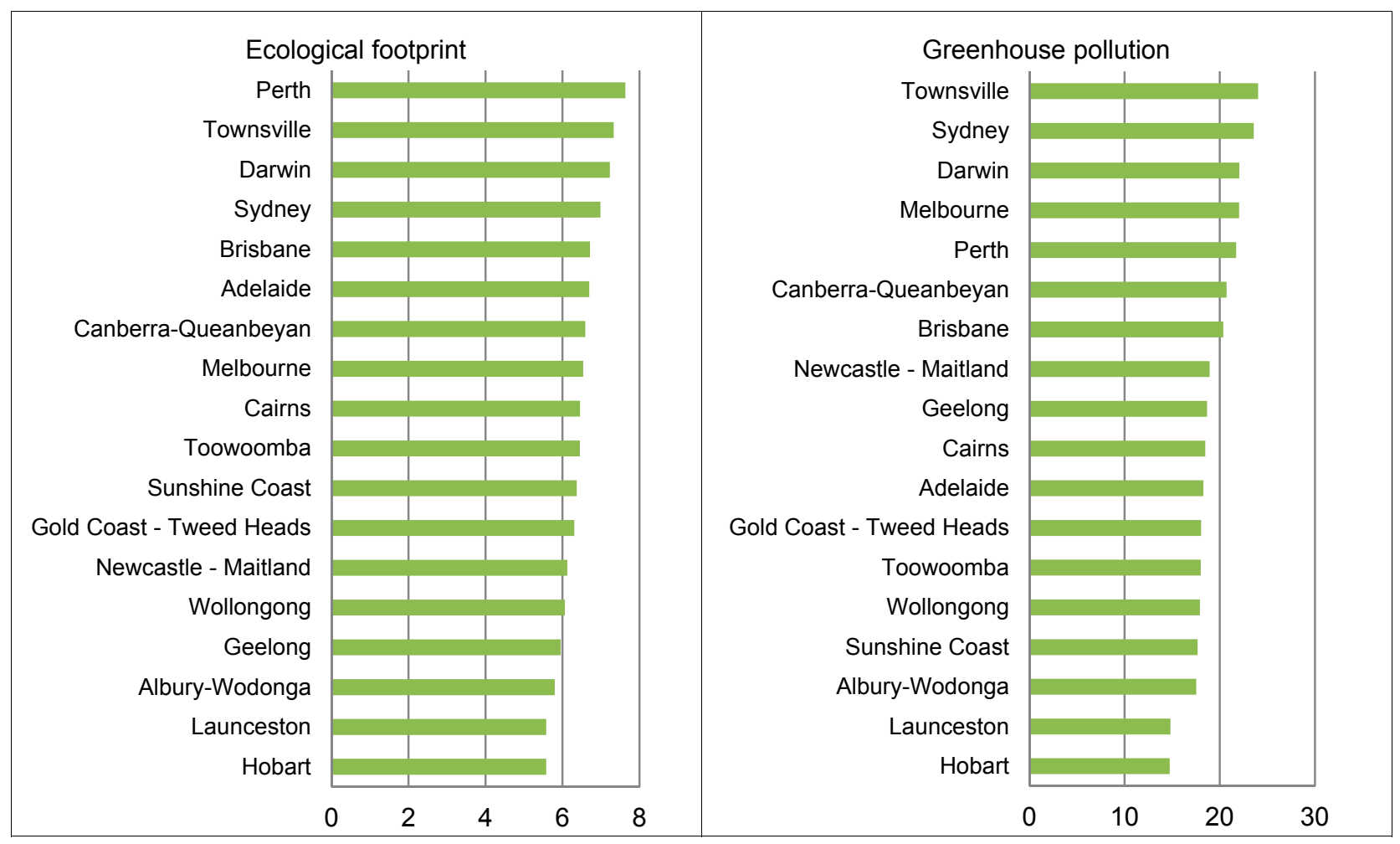

Figure 3. Cont. 


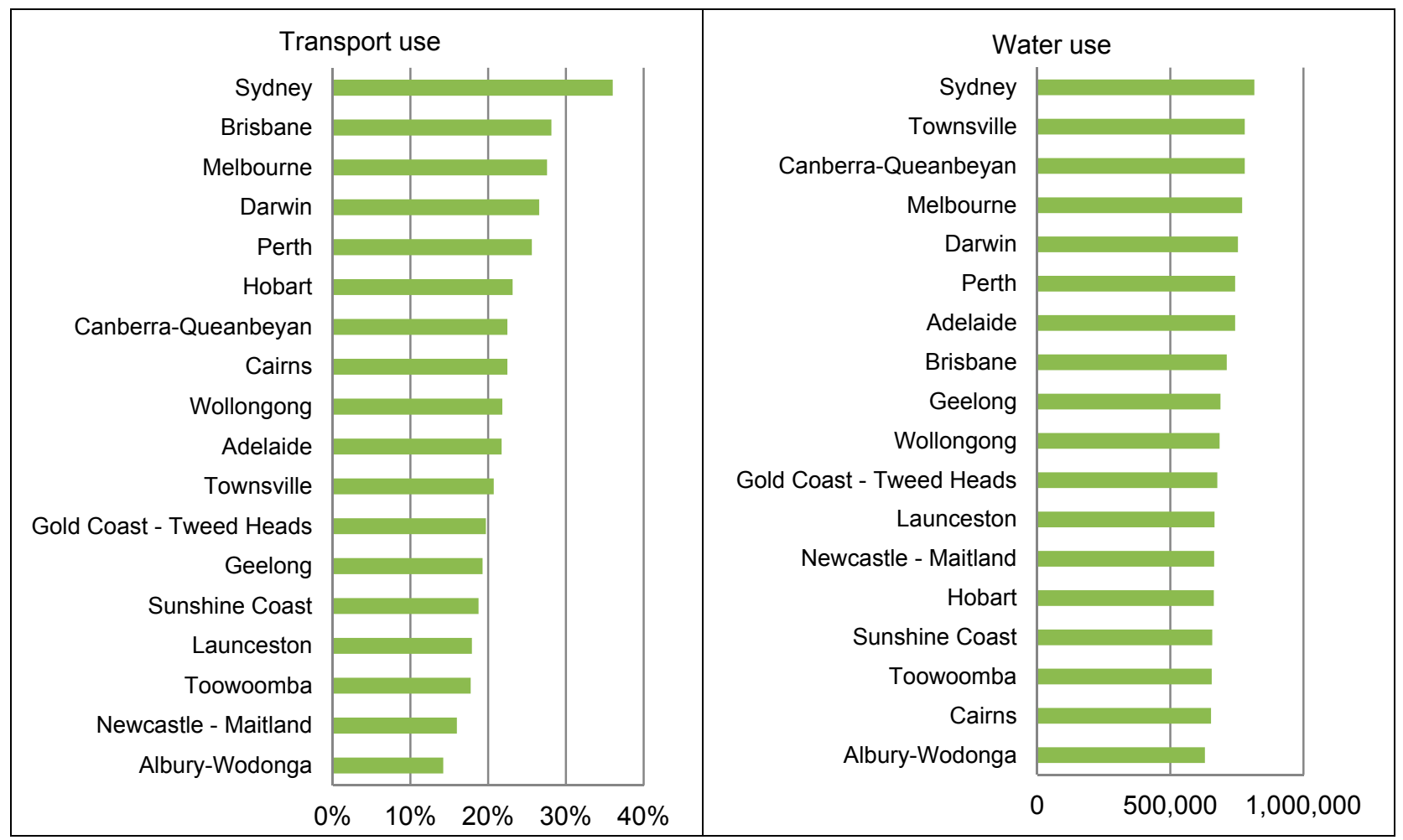

Figure 3. Sustainability indicators of major Australian cities.

\subsection{Sustainability vs. Competitiveness}

The relationship between sustainability and competitiveness in Australian cities is measured by standardised values using the z-score. The four indicators of sustainability are highly correlated with each other: ecological footprint $v s$. greenhouse pollution $(r=0.855)$; ecological footprint $v s$. transport use $(r=0.546)$; ecological footprint $v s$. water use $(r=0.718)$; greenhouse pollution $v s$. transport use $(r=0.610)$; greenhouse pollution $v s$. water use $(r=0.833)$; transport use $v s$. water use $(r=0.742)$. It is not counter-intuitive that a higher ecological footprint is associated with higher greenhouse pollution and water use. However, it is also noted that cities with higher sustainable transport use tend to have a higher ecological footprint, higher greenhouse pollution and higher water use. The urban competitiveness index is positively correlated with ecological footprint $(r=0.751)$ and with greenhouse pollution $(r=0.525)$; the urban competitiveness index is not correlated with either transport use or water use.

Since the ecological footprint is the most summative of a city's sustainability performance, its relationship with competitiveness is supposed to be the most representative of the sustainability and competitiveness relationship (see Figure 4). The ecological footprint index has the highest correlation with the urban competitiveness index and explains most of the variation of the urban competitiveness index $\left(R^{2}=0.564\right)$. Three subgroups of Australian cities can be identified according to the two variables. The first group of cities demonstrates high competitiveness and a high ecological footprint, which is mostly made up of Queensland cities, including Brisbane, Townsville and Darwin. The second group consists of two medium-sized cities, Sunshine Coast and Newcastle-Maitland, which have high 
competitiveness and a low ecological footprint. The third group of cities with low competitiveness and a low ecological footprint is mostly made up of smaller regional centres.

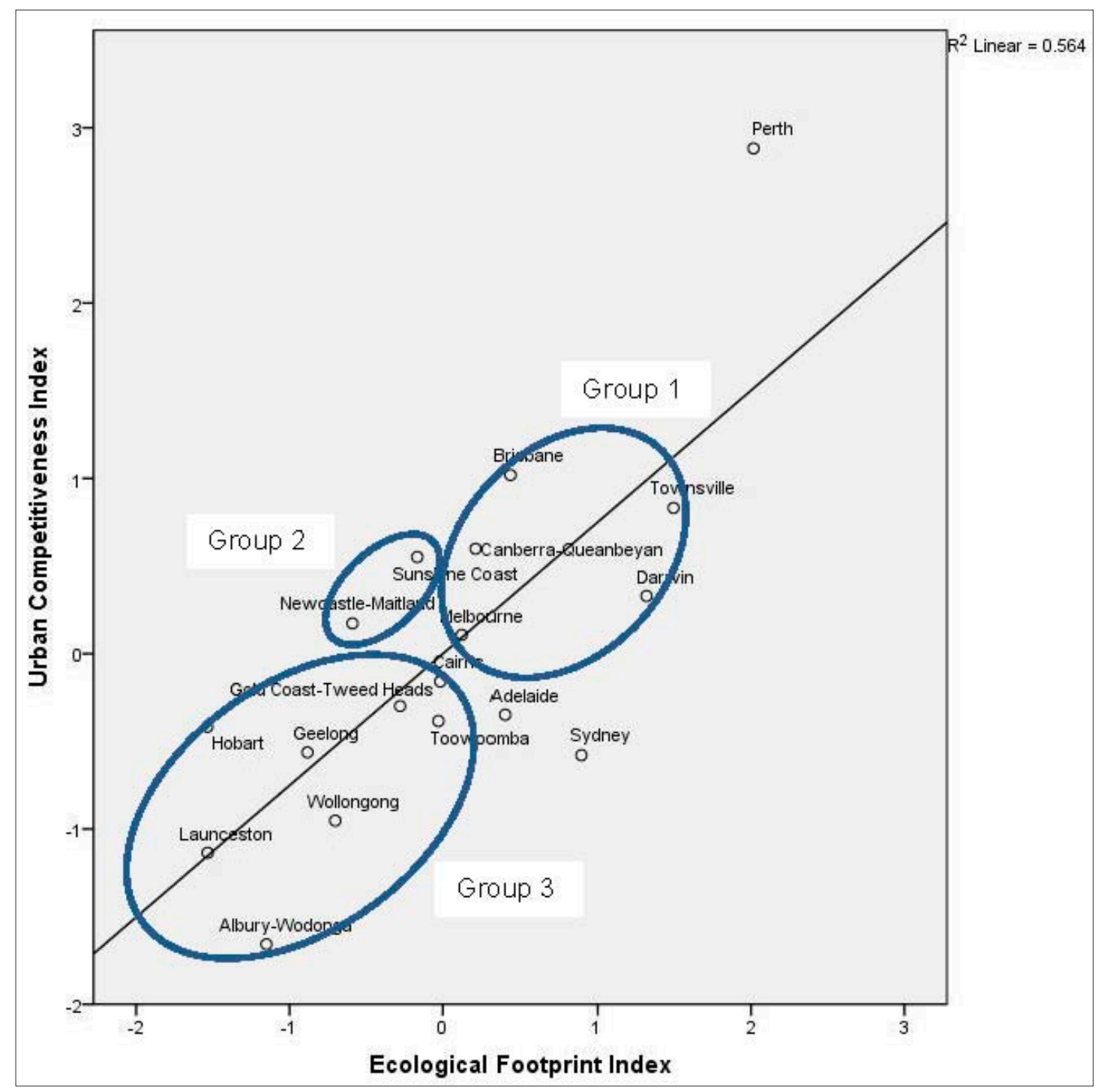

Figure 4. Urban competitiveness index and ecological footprint index.

A similar typology of Australian cities is also observed through greenhouse pollution and competitiveness (see Figure 5), through transport use and competitiveness (see Figure 6) and through water use and competitiveness (see Figure 7). However, their relationships with urban competitiveness vary. Compared with the ecological footprint index, the greenhouse pollution index is less correlated with the urban competitiveness index and explains less of the variation of the urban competitiveness index $\left(R^{2}=0.275\right)$. Transport use and water use have no correlation with urban competitiveness and have a very weak explanatory effect on urban competitiveness $\left(R^{2}=0.102\right.$ and $R^{2}=0.170$, respectively). For the first group of cities, observed through transport use and competitiveness, higher competitiveness is not associated with higher use of sustainable transport. However, for both the second and the third groups of cities, there is a clear association between increasing competitiveness and increasing transport use. No clear pattern is observed for cities classified through water use and competitiveness. 


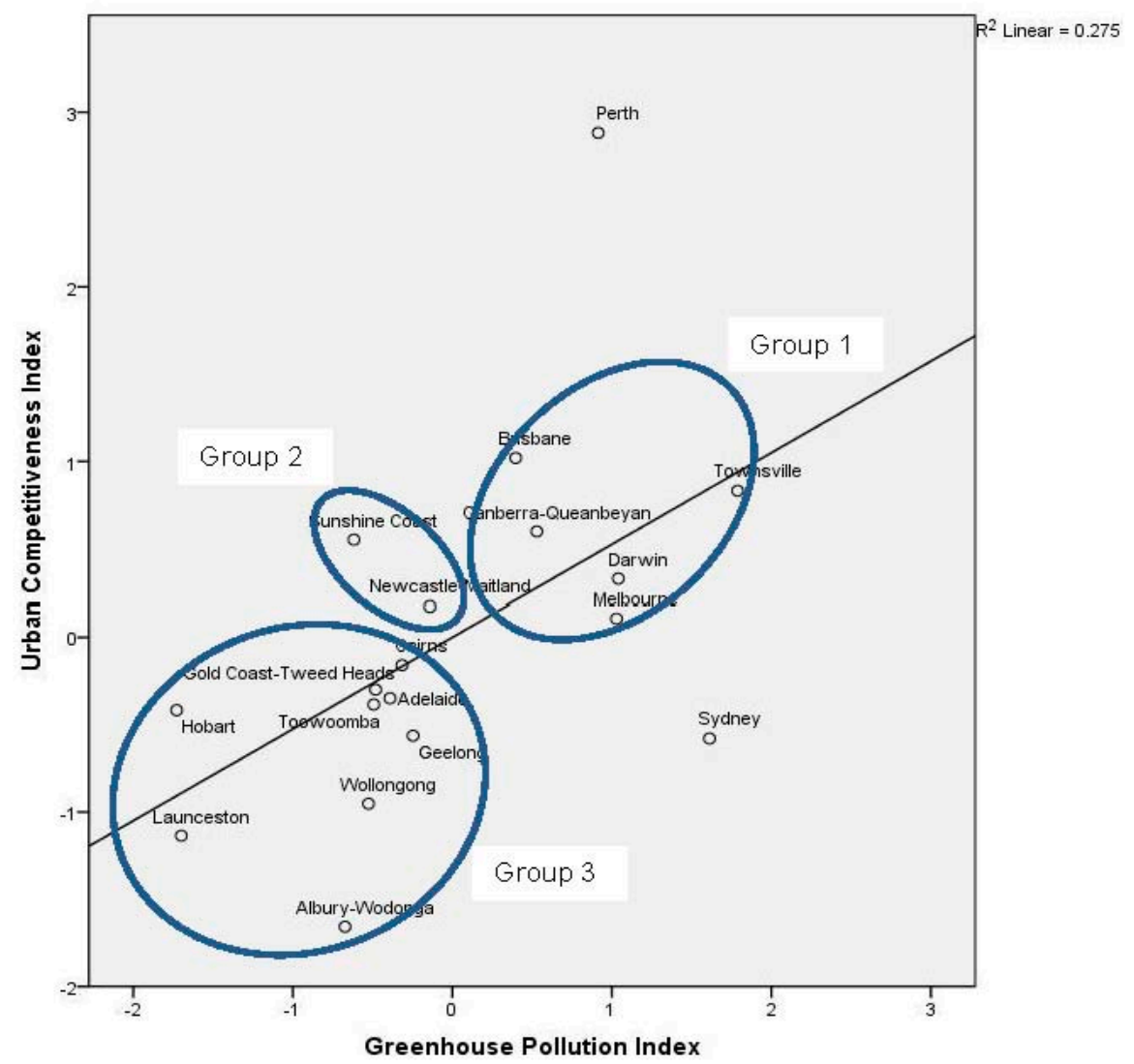

Figure 5. Urban competitiveness index and greenhouse pollution index.

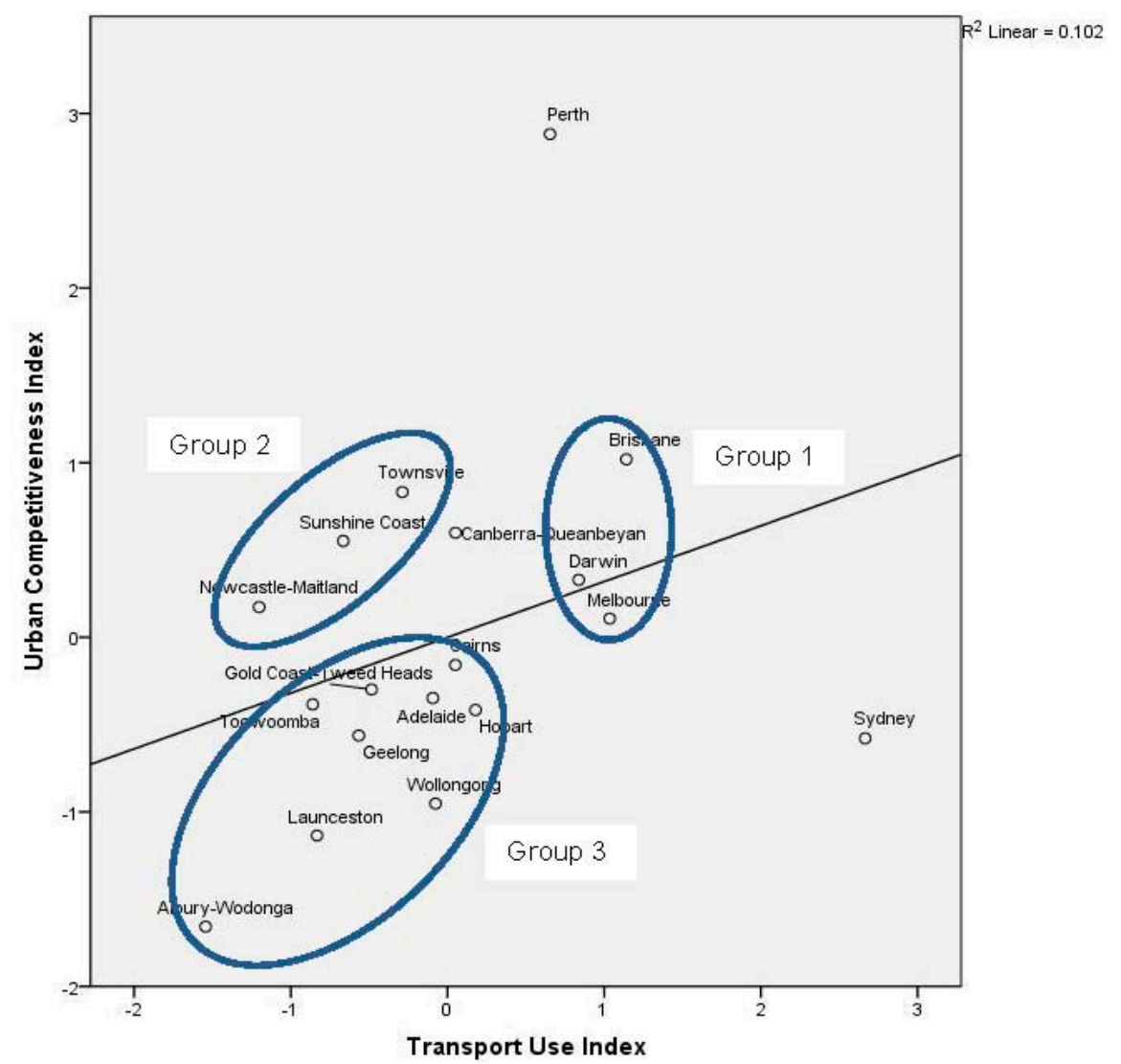

Figure 6. Urban competitiveness index and transport use index. 


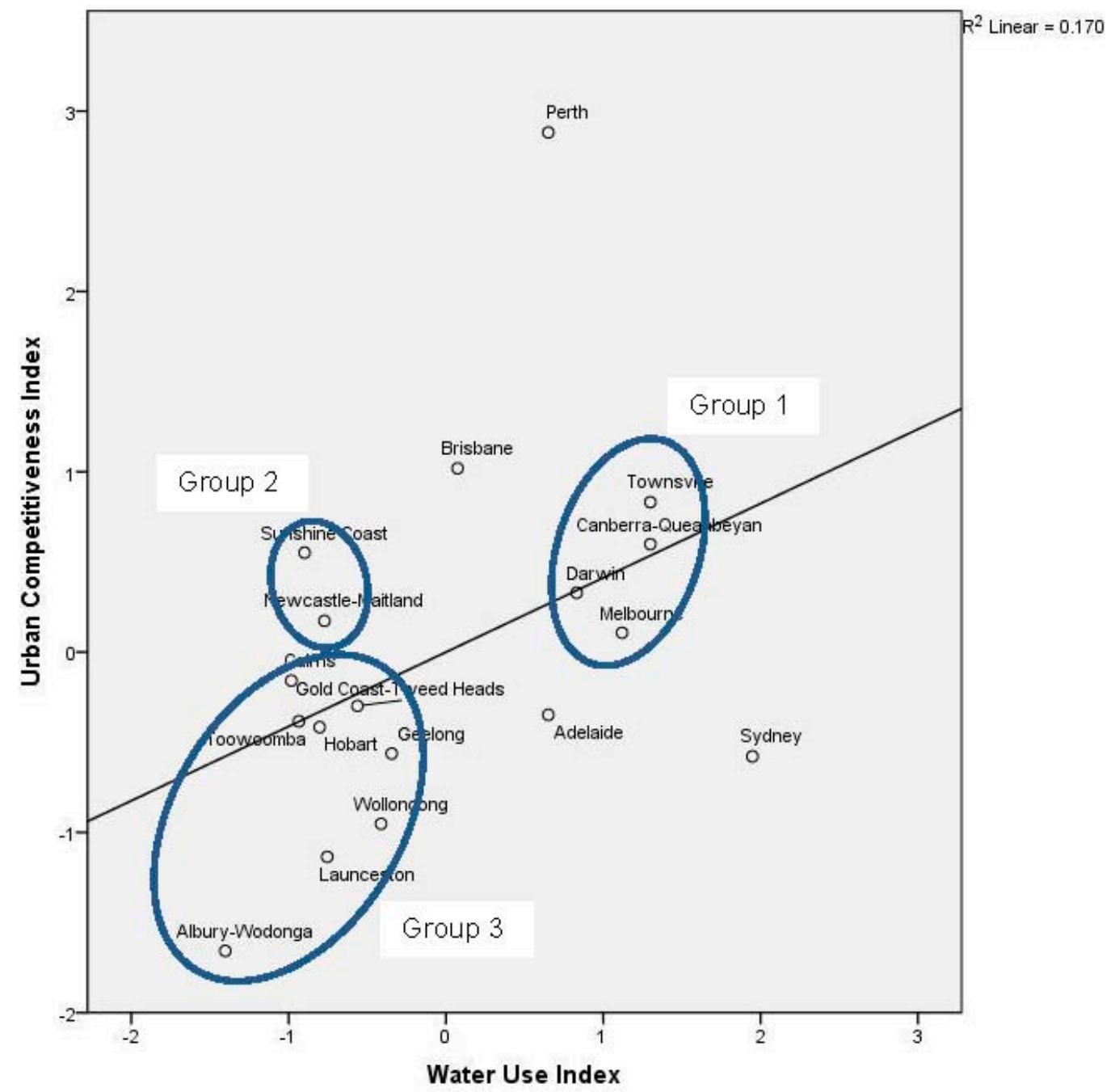

Figure 7. Urban competitiveness index and water use index.

\section{Discussion}

The approach and findings of this study contribute to both the scholarship and policy implications concerning sustainability and competitiveness. They advance the conceptualisation and methodology of urban competitiveness with an explicit concern for its relationship with sustainability. They update and enrich the understanding of sustainability and competitiveness in Australian cities. They inform policy making and planning for sustainable and competitive cities.

Linking sustainability with competitiveness and putting the two contemporary challenges under one framework provide a new approach to urban development. Injecting environmental sustainability into urban competitiveness moves beyond the economic-centric approach that has dominated the urban competitiveness discourse [8,20-26]. This study builds upon and advances the literature that suggests a need to incorporate non-economic dimensions into urban competitiveness, including environmental sustainability [27,28]. Although empirical studies have incorporated environmental sustainability into urban competitiveness, as examined in the literature review section, they differ much in both conceptualisation and methodology. This study is an effort to synthesise the literature and to propose a generalizable approach to unpack the complexity in the relationship between environmental sustainability and urban competitiveness. Much has been written about each of 
them in contemporary cities; linking both provides a refreshing perspective to inform contemporary urban development.

This study does not follow the approach of building a composite index of urban competitiveness that includes the weighting of environmental sustainability as a dimension of urban competitiveness $[2,9,15,16]$. The underpinning argument is that including the weighting of environmental sustainability into the building of an urban competitiveness index dilutes the conceptual core of 'urban competitiveness', which essentially refers to the assumption that 'cities compete'. Cities might perform better or worse in environmental sustainability; however, cities do not compete for environmental sustainability. Rather, this study uses a separate set of indicators population, employment and income, to build a composite index of urban competitiveness to capture the competition between cities for people, business and high value-added jobs. This has been informed by the study that uses payroll per employee, retail sales and professional services to measure a city's competitiveness [23], but deviates from its economic centricity. Measuring population and employment growth is underpinned by the assumption that the attraction of residents and workers to cities is not driven by economic factors only. There should be non-economic factors functioning, including sustainable environment. This assumption justifies the explanatory approach of this study, which uses a set of sustainability indicators to explain the relationship between sustainability and competitiveness in cities. It enables this study to articulate a conceptual and methodological approach to sustainability and competitiveness that can be empirically applied to cities.

The results provide the newest and the most comprehensive understanding of the competitiveness of Australian cities and their sustainability performances. Empirical studies have been undertaken to understand the competitiveness of American cities, European cities and Chinese cities [9,20-23,29-32]. This study contributes an Australian version of urban competitiveness, using a different approach, as discussed above. Previous studies on sustainability and Australian cities focused on a few large capital cities only [33,34]. This study provides an updated understanding of sustainability in Australian cities, using a new set of indicators and extending to all of the major Australian cities with a population of more than 100,000 people. This enables a holistic understanding of sustainability and competitiveness in Australian cities and their relationship in the national urban system to inform policy making and planning.

The identified relationship between sustainability and competitiveness reveals some challenging issues for Australia's urban development. Urban competitiveness is positively correlated with two important indicators of sustainability: ecological footprint and greenhouse pollution. No correlation exists between urban competitiveness and transport use or water use. Regional centres and smaller cities demonstrate a clear pattern that higher urban competitiveness is associated with higher sustainable transport use. This pattern is not observed for large capital cities. To what extent these patterns are generalizable for cities in other settings remains a question, since no data are available to compare Australian cities with cities elsewhere. However, the general pattern that urban competitiveness tends to be associated with higher environmental cost should be generalizable, for large cities in particular.

Sustainability and competitiveness are especially important issues for Australian cities. More than 85 percent of Australia's population live in urban areas, and three-quarters of Australians live in the 18 major cities included in this study [17,35]. The Australian Government [35] identified population and economic growth as two challenges facing Australian cities and environmental sustainability as a major concern, all of which are measured in this study. Internationally, unlike the United States and Europe, 
which show signs of levelling-off per capita energy use and emissions, Australia shows no clear signs of a long-term trend in that direction [18]. The claim that Australia's energy use and emissions have both climbed along with per capita GDP [18] is verified by the positive correlations between urban competitiveness and the ecological footprint and greenhouse pollution.

Sustainability and competitiveness have been incorporated into strategic policy goals for Australian cities. The Council of Australian Governments (COAG) [36] set the national objective 'to ensure Australian cities are globally competitive, productive, sustainable, liveable and socially inclusive and are well placed to meet future challenges and growth', and a set of national criteria for capital city strategic planning systems. As an implementation step of the COAG initiative, the national urban policy established the first long-term national framework for 'a productive, sustainable and liveable future' [17]. The underpinning argument is that the challenges and opportunities of productivity, sustainability and liveability are part of an interrelated and dynamic system, and addressing one goal can have an impact, either positively or negatively, on the others [17]. This study reveals that urban competitiveness, which partly relies on economic progress, is negatively correlated with environmental sustainability. The imperative for policy and planning is then how to reverse the trend and convert the negative relationship into a positive one: competitive cities can also be sustainable cities.

Urban form change and public transport improvement have long been discussed as solutions to the sustainable challenges to Australia's urban development [37]. They remain as the major policy tools. COAG's [36] national criteria for capital city strategic planning systems included nationally significant economic infrastructure, an appropriate balance of infill and greenfield development and world-class urban design and architecture. The following issues were identified for the need for change: car dependency, reducing the need for mobility, compact cities and altering the morphology of cities [38]. In reality, a change to either urban form or public transport infrastructure requires long-term strategy, investment and implementation to take effect. In addition to these conventional tools, recent advances in planning approaches and technology might offer additions or alternatives. Derived from the principles of smart growth and new regionalism, 'smart city regionalism' is an emerging policy-shaping mechanism for the fusion of competitiveness and sustainability, through advocating innovativeness, participation, collaboration and co-ordination [11].

The rise of 'smart cities' based on both digital technology and smart people working for the knowledge economy presents an opportunity to re-examine the conventional approach to urban development and planning [39]. The advancing relationship between smart cities, big data and urban form is of crucial relevance to the future of urban planning because of the radical changes it may bring to how urban environments are understood and planned. Ubiquitous technology that underpins urban infrastructure to form smart cities will ultimately shape human interactions with the urban form and influence the daily function of the city [40]. Big data gained from perpetually-streaming technology is generating massive datasets with the potential to deliver unprecedented insights into the nature of city functions and of urban problems [41]. The big data revolution in technology and science will manifest itself in the urban form, especially in regards to people behaviour modelling in urban environments [42].

These advances in thinking and technology suggest new directions for policy making and planning for the fusion of sustainability and competitiveness in cities. The two pivots of the smart city concept — smart people and smart technology—are also key elements of urban competitiveness in the 
contemporary context of a knowledge-based economy. Enabling smart work by smart people through smart technology presents new opportunities for growing a city's competitiveness. This is well captured by this study's measurement of urban competitiveness, which includes the growth of high value-added jobs. On the other hand, the smart city concept suggests possible solutions to each of the four sustainability indicators used in this study. This is made through a potential fundamental shift in the way of working and living. People do not have to commute to work on a daily basis; the behavioural division between working and living tend to be blurred. Presumably, smart work will significantly reduce private car commuting and accordingly reduce the ecological footprint, greenhouse pollution and water consumption. From an urban planning perspective, it exerts profound implications on urban space change and infrastructure provision, which are different from the conventional solutions of urban form change and public transport improvement, as discussed above. Here, the urban space change requires spatial configurations to accommodate the new way of working and living in both public and private spaces; the infrastructure provision suggests the need for more investment in digital infrastructure to facilitate smart work. This emerging direction is beginning to attract scholarly and policy attentions and is worth further observation and exploration to better understand its effectiveness in fusing competitiveness and sustainability.

\section{Conclusions}

This study moves from an economic-centric approach to urban competitiveness to employ a different perspective with an explicit concern for sustainability. Injecting sustainability into the conceptualisation and methodology of urban competitiveness sheds new light on urban development and informs policy implications to address the two challenges facing contemporary cities: sustainability and competitiveness. It expands the conceptualisation of urban competitiveness to include environmental sustainability; an explanatory framework unpacks the relationship between environmental sustainability and urban competitiveness. The conceptual and methodological approaches can be applied to cities in different settings.

The empirical findings provide a comprehensive understanding of the sustainability and competitiveness of Australian cities. They reveal the relationship between sustainability and competitiveness, which presents a challenge to policy making and planning for sustainable and competitive Australian cities. Sustainability and competitiveness are not well fused in Australia's current urban development: urban growth is highly associated with environmental cost. Apart from the conventional planning tools to change the urban form and improve public transport infrastructure, this study suggests the need to explore opportunities brought about by the emerging smart city planning approach and practice.

\section{Acknowledgments}

The author wishes to thank Lucas Carmody for assistance with data collection and analysis and Sajeda Tuli for assistance with the map. 


\section{Appendix}

Table A1. Summary of studies on environmental sustainability and urban competitiveness.

\begin{tabular}{|c|c|c|c|c|c|}
\hline $\begin{array}{l}\text { Strands of } \\
\text { Literature }\end{array}$ & $\begin{array}{c}\text { Conceptualization of Urban } \\
\text { Competitiveness }\end{array}$ & Approach to Urban Competitiveness & Component of Sustainability & $\begin{array}{l}\text { Empirical } \\
\text { Case Cities }\end{array}$ & Publications \\
\hline \multirow[t]{2}{*}{$\begin{array}{l}\text { Minor } \\
\text { component of } \\
\text { environmental } \\
\text { sustainability }\end{array}$} & $\begin{array}{l}\text { A city's ability to attract } \\
\text { capital, businesses, talent and } \\
\text { visitors. Competitiveness is a } \\
\text { holistic concept. While } \\
\text { economic size and growth } \\
\text { matter, several other factors } \\
\text { determine a city's } \\
\text { competitiveness, including its } \\
\text { business and regulatory } \\
\text { environment, its institutions, } \\
\text { the quality of human capital, } \\
\text { cultural aspects and the quality } \\
\text { of environmental governance. }\end{array}$ & $\begin{array}{l}\text { Hierarchical and composite measurement: } \\
\text { - Economic strength; } \\
\text { - Physical capital; } \\
\text { - Financial maturity; } \\
\text { - Institutional character; } \\
\text { - Social and cultural character; } \\
\text { - Human character; } \\
\text { - Environment and natural hazards; } \\
\text { - Global appeal. }\end{array}$ & $\begin{array}{l}\text { Environment and natural hazards: } \\
\text { - Risk of natural disasters } \\
\circ \text { Disaster management/business } \\
\text { continuity plan; } \\
\circ \text { Physical exposure to } \\
\text { natural hazards; } \\
\text { - Susceptibility to climate change. } \\
\text { - Environmental governance } \\
\circ \text { Water quality monitoring; } \\
\circ \text { Waste strategy; air quality code; } \\
\circ \text { Quality of air in the city/pollution. }\end{array}$ & $\begin{array}{l}120 \text { cities } \\
\text { across the } \\
\text { world }\end{array}$ & {$[12]$} \\
\hline & $\begin{array}{l}\text { The condition in which one } \\
\text { city is relatively more efficient } \\
\text { at producing wealth and at } \\
\text { providing welfare for its } \\
\text { citizens than other cities, } \\
\text { regardless of city location, } \\
\text { function and industry. }\end{array}$ & $\begin{array}{l}\text { Composite measurement: } \\
\text { - GDP; } \\
\text { - GDP/km²; } \\
\text { - Growth rate of GDP. } \\
\text { Explanatory approach: } \\
\text { - Hard factors } \\
\text { o Labour and human capital; } \\
\text { ○ Local demand; } \\
\text { ○ Financial and physical capital; } \\
\text { ○ Technology and innovation; } \\
\text { ○ Outside connection and openness; } \\
\text { ○ Infrastructure; } \\
\text { ○ Agglomeration of industries and cities; } \\
\text { o Natural geographic location; } \\
\text { ○ Ecological environment. } \\
\text { - Soft factors } \\
\text { o Government regulation and service; } \\
\text { ○ Institutional capital; } \\
\text { o Culture and social values. }\end{array}$ & Ecological environment & $\begin{array}{l}25 \text { Chinese } \\
\text { cities }\end{array}$ & [13] \\
\hline
\end{tabular}


Table A1. Cont.

\begin{tabular}{|c|c|c|c|c|c|}
\hline $\begin{array}{l}\text { Strands of } \\
\text { Literature }\end{array}$ & $\begin{array}{c}\text { Conceptualization of Urban } \\
\text { Competitiveness }\end{array}$ & Approach to Urban Competitiveness & Component of Sustainability & $\begin{array}{c}\text { Empirical } \\
\text { Case Cities }\end{array}$ & Publications \\
\hline & $\begin{array}{l}\text { Urban competitiveness based } \\
\text { on regeneration- and } \\
\text { property-linked } \\
\text { business strategies. }\end{array}$ & $\begin{array}{l}\text { Hierarchical and composite measurement: } \\
\text { - Physical environment; } \\
\text { - Social capital; } \\
\text { - Finance; } \\
\text { - Development; } \\
\text { - Investment; } \\
\text { - User potential. }\end{array}$ & $\begin{array}{l}\text { - Physical environment } \\
\text { o Optimizing ecological footprint. } \\
\text { - Development } \\
\text { o Promoting environmentally } \\
\text { responsible property development. }\end{array}$ & 5 Indian cities & {$[14]$} \\
\hline $\begin{array}{l}\text { Major } \\
\text { component of } \\
\text { environmental } \\
\text { sustainability }\end{array}$ & $\begin{array}{l}\text { Urban competitiveness is } \\
\text { complex and multidimensional } \\
\text { (including environment, } \\
\text { industry development, } \\
\text { services, welfare, etc.). }\end{array}$ & $\begin{array}{l}\text { Hierarchical and composite measurement: } \\
\text { - Economic competitiveness; } \\
\text { - Social-cultural competitiveness; } \\
\text { - Environmental competitiveness; } \\
\text { - Locational competitiveness. }\end{array}$ & 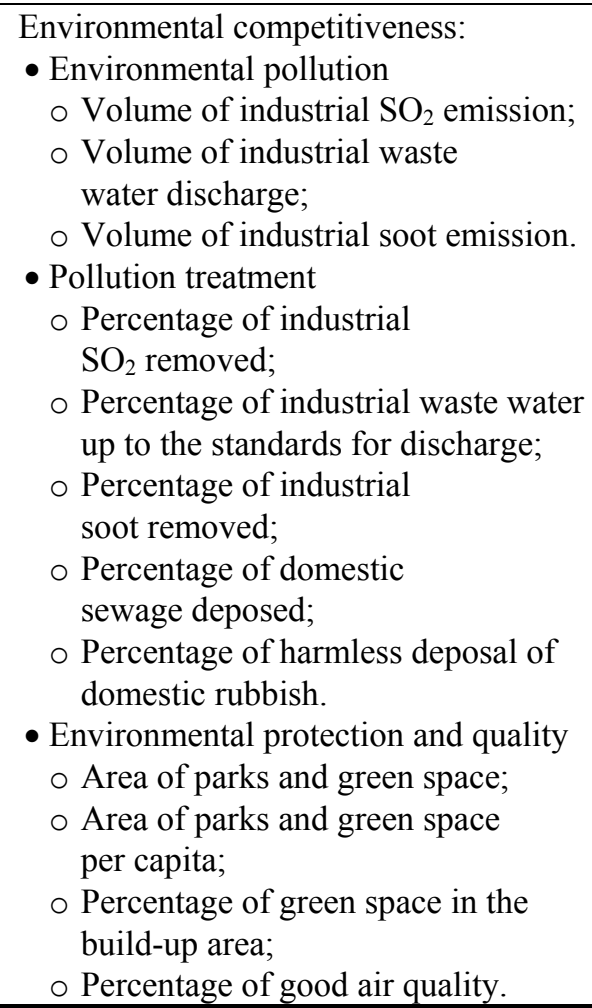 & $\begin{array}{l}31 \text { Chinese } \\
\text { provincial } \\
\text { capital cities }\end{array}$ & {$[15]$} \\
\hline
\end{tabular}


Table A1. Cont.

\begin{tabular}{|c|c|c|c|c|c|}
\hline $\begin{array}{l}\text { Strands of } \\
\text { Literature }\end{array}$ & $\begin{array}{c}\text { Conceptualization of Urban } \\
\text { Competitiveness }\end{array}$ & Approach to Urban Competitiveness & Component of Sustainability & $\begin{array}{l}\text { Empirical } \\
\text { Case Cities }\end{array}$ & Publications \\
\hline & $\begin{array}{l}\text { A sustainable development } \\
\text { perspective to use economic, } \\
\text { social and environmental } \\
\text { dimensions to conceptualize } \\
\text { urban competitiveness. }\end{array}$ & $\begin{array}{l}\text { Hierarchical and composite measurement: } \\
\text { - Economic competitiveness component } \\
\text { ○ Economic performance; } \\
\text { ○ Economic structure and capacity; } \\
\text { ○ Marketization and openness. } \\
\text { - Social competitiveness component } \\
\text { ○ Human resources and education; } \\
\text { ○ Quality of life; } \\
\text { ○ Level of urban development; } \\
\text { ○ Government operation and initiatives. } \\
\text { - Environmental competitiveness component }\end{array}$ & $\begin{array}{l}\text { Environmental competitiveness } \\
\text { component: } \\
\text { - Amount of } \mathrm{SO}_{2} \text { per unit of urban area; } \\
\text { - Percentage of industrial sewage } \\
\text { discharged meeting national standard; } \\
\text { - Percentage of area meeting national } \\
\text { standard of environmental noise; } \\
\text { - Percentage of green space in the } \\
\text { built-up area; } \\
\text { - Area of parks and green areas } \\
\text { per capita; } \\
\text { - Number of prizes achieved for quality } \\
\text { of environment. }\end{array}$ & $\begin{array}{l}253 \text { Chinese } \\
\text { cities at the } \\
\text { prefecture level } \\
\text { or above }\end{array}$ & [9] \\
\hline & $\begin{array}{l}\text { A city's competitiveness is } \\
\text { measured by economic, social, } \\
\text { environmental and external } \\
\text { connectivity components. }\end{array}$ & 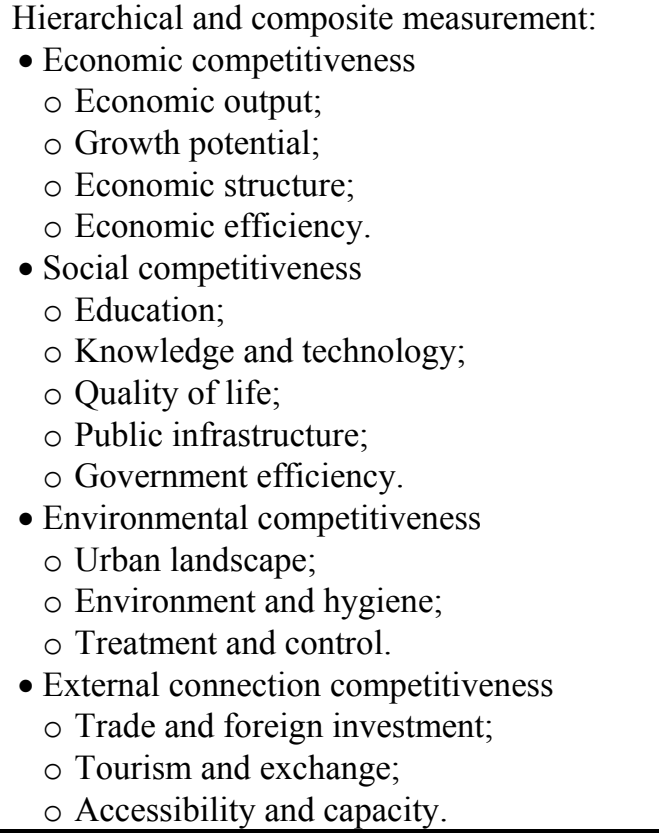 & $\begin{array}{l}\text { Environmental competitiveness: } \\
\text { - Urban landscape } \\
\text { ○ Green coverage rate in built-up area; } \\
\text { ○ Public green space per capita; } \\
\text { ○ National garden city award. } \\
\text { - Environment and hygiene } \\
\text { ○ Domestic wastewater treatment rate; } \\
\text { ○ Harmless disposal rate of } \\
\text { domestic waste; } \\
\text { ○ National hygienic city award. } \\
\text { - Treatment and control } \\
\text { O Percentage of industrial wastewater } \\
\text { reaching the discharge standards; } \\
\text { ○ Percentage of industrial solid } \\
\text { wastes utilized; } \\
\text { O Traffic noise in downtown roads; } \\
\text { ○ Urban construction and maintenance } \\
\text { fund per capita. }\end{array}$ & $\begin{array}{l}24 \text { major } \\
\text { Chinese cities }\end{array}$ & {$[16]$} \\
\hline
\end{tabular}


Table A1. Cont.

\begin{tabular}{|c|c|c|c|c|c|}
\hline $\begin{array}{l}\text { Strands of } \\
\text { Literature }\end{array}$ & $\begin{array}{c}\text { Conceptualization of Urban } \\
\text { Competitiveness }\end{array}$ & Approach to Urban Competitiveness & Component of Sustainability & $\begin{array}{c}\text { Empirical } \\
\text { Case Cities }\end{array}$ & Publications \\
\hline & $\begin{array}{l}\text { An integrative model of urban } \\
\text { competitiveness that includes } \\
\text { economic and non-economic } \\
\text { dimensions and incorporates } \\
\text { both determinants and } \\
\text { indicators of a city's } \\
\text { competitiveness. }\end{array}$ & $\begin{array}{l}\text { Hierarchical and composite measurement: } \\
\text { - Governance; } \\
\text { - Environmental sustainability; } \\
\text { - Enterprise hub; } \\
\text { - Liveability and attractiveness; } \\
\text { - Creativity and diversity; } \\
\text { - Connectivity. }\end{array}$ & $\begin{array}{l}\text { Environmental sustainability: } \\
\text { - Air quality; } \\
\text { - Energy consumption; } \\
\text { - Private vehicle ownership. }\end{array}$ & $\begin{array}{l}12 \text { global cities } \\
\text { (a focus on } \\
\text { Sydney and } \\
\text { Melbourne) }\end{array}$ & {$[2]$} \\
\hline & $\begin{array}{l}\text { A city's competitiveness is } \\
\text { reflected by a city's progress in } \\
\text { growing jobs, attracting people } \\
\text { and offering more high } \\
\text { value-added opportunities. }\end{array}$ & $\begin{array}{l}\text { Composite measurement: } \\
\text { - Employment growth; } \\
\text { - Population growth; } \\
\text { - Income growth. } \\
\text { Explanatory approach: } \\
\text { - Economic performance (productivity); } \\
\text { - Environmental performance (sustainability); } \\
\text { - Social performance (liveability). }\end{array}$ & $\begin{array}{l}\text { Environmental performance } \\
\text { (sustainability): } \\
\text { - Transport (proportion of people using } \\
\text { public transport, walking, car sharing } \\
\text { or riding to commute); } \\
\text { - Ecological footprint (land resources } \\
\text { per person per year). }\end{array}$ & $\begin{array}{l}18 \text { major } \\
\text { Australian } \\
\text { cities (a focus } \\
\text { on Canberra) }\end{array}$ & [1] \\
\hline
\end{tabular}




\section{Conflicts of Interest}

The author declares no conflicts of interest.

\section{References}

1. $\mathrm{Hu}, \mathrm{R}$. Canberra's competitiveness in the national context. Policy Stud. 2015, doi:10.1080/ 01442872.2014.981058.

2. Hu, R.; Blakely, E.J.; Zhou, Y. Benchmarking the competitiveness of Australian global cities: Sydney and Melbourne in the global context. Urban Policy Res. 2013, 31, 435-452.

3. Krugman, P. Making sense of the competitiveness debate. Oxf. Rev. Econ. Policy 1996, 12, $17-25$.

4. Krugman, P. Urban concentration: The role of increasing returns and transport costs. Int. Reg. Sci. Rev. 1996, 19, 5-48.

5. Porter, M. The competitive advantage of the inner city. Harv. Bus. Rev. 1995, 73, 55-71.

6. Porter, M. Competitive advantage, agglomeration economies and regional policy. Int. Reg. Sci. Rev. 1996, 19, 85-90.

7. Begg, I. Cities and competitiveness. Urban Stud. 1999, 36, 795-809.

8. Boddy, M.; Parkinson, M. City Matters: Competitiveness, Cohesion and Urban Governance; The Policy Press: Bristol, UK, 2004.

9. Jiang, Y.; Shen, J. Measuring the urban competitiveness of Chinese cities in 2000. Cities 2010, 27, 307-314.

10. Gilli, M.; Mazzanti, M.; Nicolli, F. Sustainability and competitiveness in evolutionary perspective: Environmental innovations, structural change and economic dynamics in the EU. J. Soc. Econ. 2013, 45, 204-215.

11. Herrschel, T. Competitiveness and sustainability: Can 'smart city regionalism' square the circle? Urban Stud. 2013, 50, 2332-2348.

12. The Economist Intelligence Unit. Hot Spots 2025: Benchmarking the Future Competitiveness of Cities; The Economist Intelligence Unit Limited: London, UK; New York, NY, USA; Hong Kong, China; Geneva, Switzerland, 2013.

13. Ni, P.; Kresl, P.; Li, X. China urban competitiveness in industrialization: Based on the panel data of 25 cities in China from 1990 to 2009. Urban Stud. 2014, 51, 2787-2805.

14. Singhal, S.; McGreal, S.; Berry, J. Application of a hierarchical model for city competitiveness in cities of India. Cities 2013, 31, 114-122.

15. Du, Q.; Wang, Y.; Ren, F.; Zhao, Z.; Liu, H.; Wu, C.; Li, L.; Shen, Y. Measuring and analysis of urban competitiveness of Chinese provincial capitals in 2010 under the constraints of major function-oriented zoning utilizing spatial analysis. Sustainability 2014, 6, 3374-3399;

16. Shen, J.; Yang, X. Analyzing urban competitiveness changes in major Chinese cities 1995-2008. Appl. Spat. Anal. Policy 2014, doi:10.1007/s12061-014-9114-2.

17. Australian Government. Our Cities, Our Future; Department of Infrastructure and Transport: Canberra, Australia, 2011. 
18. Australian Government. State of Australian Cities 2013; Department of Infrastructure and Transport: Canberra, Australia, 2013.

19. Australian Conservation Foundation. Consuming Australia; Australian Conservation Foundation: Melbourne, Australia, 2007.

20. Kresl, P.K. The Determinants of Urban Competitiveness: A Survey. In North American Cities and the Global Economy: Challenges and Opportunities; Kresl, P.K., Gappert, G., Eds.; Sage Publications: Thousand Oaks, CA, USA, 1995; pp. 45-68.

21. Kresl, P.K.; Singh, B. The competitiveness of cities: The United States. In Cities and the New Global Economy; The Government of Australia and the OECD: Melbourne, Australia, 1994; pp. 424-446.

22. Kresl, P.K.; Singh, B. Competitiveness and the urban economy: Twenty-four large US metropolitan areas. Urban Stud. 1999, 36, 1017-1027.

23. Kresl, P.K.; Singh, B. Urban competitiveness and US metropolitan centres. Urban Stud. 2012, 49, 239-254.

24. Rogerson, R.J. Quality of life and city competitiveness. Urban Stud. 1999, 36, 969-985.

25. Turok, I. Cities, regions and competitiveness. Reg. Stud. 2004, 38, 1069-1083.

26. Budd, L.; Hirmis, A. Conceptual framework for regional competitiveness. Reg. Stud. 2004, 38, 1015-1028.

27. Petrella, R. The future of regions: Why the competitiveness imperative should not prevail over solidarity, sustainability and democracy. Geogr. Ann. 2000, 82, 67-72.

28. Bulkeley, H.; Betsill, M. Rethinking sustainable cities: Multilevel governance and the 'urban' politics of climate change. Environ. Polit. 2005, 14, 42-63.

29. Jensen-Butler, C.; Shachar, A.; Weesep, J.V. European Cities in Competition; Avebury: Aldershot, UK, 1997.

30. Ranci, C. Competitiveness and social cohesion in Western European cities. Urban Stud. 2011, 48, 2789-2804.

31. Lever, W.F. Competitive cities in Europe. Urban Stud. 1999, 36, 1029-1044.

32. Greene, F.J.; Tracey, P.; Cowling, M. Recasting the city into city-regions: Place promotion, competitiveness benchmarking and the quest for urban supremacy. Growth Chang. 2007, 38, $1-22$.

33. Moriarty, P. Environmental sustainability of large Australian cities. Urban Policy Res. 2002, 20, 233-244.

34. Newman, P. Sustainability and Australian cities. Aust. Plan. 1999, 36, 93-100.

35. Australian Government. Australia State of the Environment; Department of Sustainability, Environment, Water, Population and Communities: Canberra, Australia, 2011.

36. Council of Australian Governments. Council of Australian Governments' Meeting Communique; Council of Australian Governments: Brisbane, Australia, 2009.

37. Luk, J.Y.K. Reducing car travel in Australian cities: Review report. J. Urban Plan. Dev. 2003, 129, 84-96.

38. Australian Sustainable Built Environment Council. Cities for the Future: Baseline Report and Key Issue; Australian Sustainable Built Environment Council: Sydney, Australia, 2010.

39. Kitchin, R. The real-time city? Big data and smart urbanism. GeoJournal 2014, 79, 1-14. 
40. Zanella, A.; Bui, N.; Castellani, A.; Vangelista, L.; Zorzi, M. Internet of things for smart cities. Internet Things J. IEEE 2014, 1, 22-32.

41. Tien, J. Big data: Unleashing information. J. Syst. Sci. Syst. Eng. 2013, 22, 127-151.

42. Keller, S.A.; Koonin, S.E.; Shipp, S. Big data and city living - What can it do for us? Significance 2012, 9, 4-7.

(C) 2015 by the author; licensee MDPI, Basel, Switzerland. This article is an open access article distributed under the terms and conditions of the Creative Commons Attribution license (http://creativecommons.org/licenses/by/4.0/). 